\title{
A Contrastive Study on the Associative Meanings of Basic Color Terms in English and Chinese
}

\author{
Xiaoyan $\mathrm{Wu}$ \\ School of Foreign Languages, Hubei University, Wuhan, China \\ 1287106324@qq.com
}

Keywords: Basic color terms; Associative meanings; Similarities; Differences; Reasons

\begin{abstract}
We use various colors to describe our world and express our feelings. As a result of different language cultures, historical backgrounds, religious beliefs, modes of thinking, political systems, traditional customs and so on in different nationalities, the associative meanings produced by the color have nothing in common with each other. So learners have some difficulty in understanding the color terms. In this essay, I will mainly discuss similarities and differences of associative meaning of six basic color terms in English and Chinese. I hope this essay is helpful to communication and understanding of Chinese and English cultures.
\end{abstract}

\section{Introduction}

People's actual life is closely related to color. There are many color expressions, which reflect different culture psychologies and emotional factors both in Chinese and English languages. Theoretically, the color words are no difference in literal meaning. However, because of various language cultures, religious beliefs, modes of thinking, political system and so on in different nationalities, the associative meanings produced by the color have nothing in common with each other. Although it is difficult to find equivalent expressions in target language, this thesis will try to find out similarities and differences of associative meaning of basic color terms in English and Chinese. Not only can this help us understand various cultural differences and customs but also contribute to avoiding misunderstanding and misuse in the intercultural communication. What's more, understanding basic color terms can benefit English teaching and translation.

\section{Basic Color Terms and Its Associative Meaning}

Basic Color Terms. Color words are countless, and different nationalities have their own color vocabulary systems. What colors can be identified as basic color words? Foreign linguists put forward that human language includes 11 basic color terms: white, black, red, green, yellow, blue, brown, purple, pink, orange and gray. Most foreign scholars agree human neurophysiologic structures determine that there are six main color categories in human languages, which are: red, yellow, blue, green, black and white. And other colors all derive from these six basic colors. Zhan Renfeng of Chinese scholar thought that in Chinese there are six basic color terms: black, white, red, yellow, green, blue [1]. The basic color words are used commonly both in English and Chinese.

Associative Meanings of Basic Color Terms. Language is an indispensable carrier of culture[2]. Because of the differences between customs, religions and value orientation and so on, a word with the same definition may carry different associative meanings in different culture. On one hand, they reflect a nation's understanding of natural environment ("red" for sun, fire and blood, "green" for living plants, "blue" for sky and sea [3]). On the other hand, they can meet the cultural needs of different nations so as to show one's world outlook, philosophy, hierarchy, etc. For example, in China, people wear red clothes to show happiness and white clothes to show grief while in Europe people wear white clothes to celebrate wedding and they seldom wear white clothes on a funeral. Language is deeply rooted in the culture of a nation. Therefore, learning the connotative meanings of language is essential in understanding another culture's verbal code. 


\section{Contrast of Associative Meanings of Basic Color Terms in Chinese and English}

Similarities of Associative Meanings of Basic Color Terms in English and Chinese. Red and 红

(1)Red and 红 symbolize happiness, prosperity, warmth, celebration, pleasure, love, yearning, shyness, etc. China is a country where red is admired because the Han nationality is the first in the world to make use of fire [4]. 红对联,红盖头,红包, 红蛋 stands for happiness. Match-maker is named 红娘. Besides, in Chinese, a very famous trademark 红双喜 is symbolic of good fortune. 开门红,满堂红,红火,红运,红利,走红,红得发紫 refer to prosperity.红 are associated with pleasure, love and yearning in the phrases 红人,红娘, 红颜 and the following poems 日出江花红似火,春来 江水绿如蓝(白居易); 霜叶红于二月花(杜牧); 红杏枝头春意闹(宋祁); 感此伤妾心,坐愁红颜老 (李白);红豆生南国,春来发几枝;愿君多采摘,此物最相思(王维) and O, my Luve’s like a red, red rose (Robert Burns). In addition, the girls in China like wearing red lines to fasten their hair and using 红 as their names, like 小红,艳红 and so on. In English-speaking countries, for instance, “a red-letter day" is a day of importance or worth memory for holidays, festivals and saints' days are marked on the calendars since the $15^{\text {th }}$ century. The expression "paint the town red" comes from the United States indicating that during the festivals, all lights are decorated, all the walls are renovated and people are enjoying themselves. In English, her face turned red or to become red-faced shows one's embarrassment, as it does in Chinese“脸红”. (2)Red and 红 are associated with cruelty, disaster, anger, potential danger and death, etc.红 in the following phrases 白刀子进去, 红刀子出 来,刺刀见红, 杀红了眼 are related to violence and cruelty. 争得脸红脖子粗 and 他们从没红过脸 express anger.红喜事 means death. In English, "red battle", "red alert", “ red light" and "red label" are related to war and potential danger[5]. "Catch somebody red-handed" initially referred to fresh blood on the hands of murders while afterwards it means "to catch somebody on the spot". Communists are labeled a "Red". "Like a red rag to a bull" means being angry with everybody around like a crazy bull incited by a red rag. So "red rag" is often referred to something to make somebody angry or mad. "See red" means somebody is angry or annoyed because of something which has been said or done. (3)Both Red and 红 are symbolic of pornography, health and nobleness. Chinese people like to describe love affair with 红, such as 红杏出墙,倚红偎翠. All these love affairs are called 绯闻. The Chinese idiom 满面红光 means ruddy or rubicund cheeks, and the English compound adjective "red-blooded" corresponds with the Chinese proverb 人凭血强, 月凭日贵.红 and 朱 can both apply to the description of power and nobleness, like 满朝朱紫贵,红 顶商人,红头文件,etc. "Rosy cheeks" and “a face as red as a rose" respond to 红润的脸项 in Chinese.花街柳巷 corresponds with “red light district", which is a well-known euphemism indicating some locations where sexual business is going on. It is said to be used first in Dodge city in a state of the U.S. for red lights were hung in those locations as a sort of attraction mark. More examples are as follows "a red waste of his youth", "Is she really so red as she is painted?" . "Red" in western history, mainly before $13^{\text {th }}$ century, king and his fellows wore red clothes, church's decoration was also in red.

Yellow and 黄(1)Both “yellow" and 黄 symbolize illness, warning, danger and pornography. Yellow is associated with unhealth, such as: in English "yellow blight" and "yellow fever", in Chinese 面黄肌瘦. “A yellow flag” hung on a ship indicates that some sailors have caught up with certain epidemic. A "yellow card", which the judge shows a sportsman if he fails to comply with the competition rules, can be used to hint a warning. "Double-yellow-line" is a mark of traffic danger both in the west and east. In America, some dirty, filthy or porn books and periodicals were printed with paper somewhat a little bit yellow, so it is associated with porn, dirty or derogative, such as “ yellow journalism”, while in Chinese 黄色报刊,黄色办报作风,扫黄 have meanings of obscenity and pornography[6]. (2)Both “yellow" and 黄 stand for desolation, withering, decline, depression and death. When the autumn comes, all the plants and trees turn yellow, then the dead leaves fall onto the ground. The autumn fills the world with a dull and dreary view, so both the westerners and the easterners tend to associate "yellow" or 黄 with desolation, decline, depression 
and death. In English, in Ode to the West Wind Percy Shelley used dead leaf to refer to "yellow leaf". "My way of life is fallen into the sear yellow leaf" expresses desolation. Lu Lun, a talented poet in the Tang Dynasty, sighed in his poem Autumn Leaves(《忧伤》): 岁去人白头, 秋来树叶 黄, 搔头向黄叶, 与尔共悲伤. In Chinese, in Li Qinzhao's poem 莫道不消魂, 帘卷西风, 人比黄 花瘦, the poetess gave us a vivid and delicate description of her solitude in the bleak and desolate autumn. 人老珠黄 is used to describe old and ugly women with the passing of the years, 黄泉 means the place where the dead were buried. (3)Yellow and 黄 stand for preciousness, wealth and perfectness. In the ancient time, the rich people wore gold jewelry to show their wealth. Han nationality uses 黄 while the English-speaking countries replace word "yellow" with "golden" to indicate preciousness and perfectness, such as: in Chinese 黄金周,黄金地段,黄金年华,黄金时代, 黄金时机, in English “golden week"; “prime time”; "golden age"; "golden times" and "golden opportunity" and so on[7]

Blue and 蓝 (1)The color "blue" in English and 蓝 in Chinese are the color of sky and sea, and always arouses the feeling of calmness and justice. “Blue sky” is often called“青云”“青天”, and "blue sea” is “大海” in Chinese. Blue means justice. For example: Shakespeare compared Heaven to King of God in Henry V1ll: Heaven is above all yet. There sits a Judge. That no king can corrupt.

Green and 绿 (1)Green is linked with spring, nature and symbolizes vigor, youth and a person good at planting. No matter in English or Chinese, "green" is mainly related to the color of the plants, it is the symbol of vigor and energy, such as: "in the green wood", "in the green", "a green old age” and “the green years”. An example in Chinese:春风又绿江南岸, 明月何时照我还?（王安 石) it describes a vigorous spring scene. “Green fingers" and "green thumb" means somebody is good at planting. (2)Green represents environmental protection, peace, friendship and hope. The pollution is worse and worse, people begin to realize the importance of the environment. In English, "Greenish" refers to be sympathetic towards the environment. What's more, the "Green Belt" refers to an area of land around the city where building is not allowed in order to protect fields and woods. In the west, "the Green Peace Organization" was set up in Canada in 1971 in order to protect environment, "green politics", "green consumerism" and "green grocer" are related to environmental protection. A "green olive" branch in the dove's mouth is a symbol of peace and friendship. “In green winter” means warm winter. In Chinese, we have 绿色食品, 绿色革命, 绿色 消费. (3)Green means giving permission to do ahead. In English "giving permission to" is related to (开)绿灯 in Chinese, 绿卡 is a card that a foreigner must have in order to work legally in America.

White and 白 (1)White and 白 suggests purity, innocence, brightness, beauty, fairy and honesty. "White" in the western culture is usually an esteem color. "White" is considered purity. Therefore, "White" is the traditional color for the brides at weddings, which symbolizes purity of the new-wedding couple. "Make one's name white again" refers to wiping out disgrace and regain purity. "White hands" means honesty in performing one's official duties, "white light" means fair judgement. The Chinese expressions 不白之冤, 清白无辜, 清清白白做人, 洁白如玉, 白玉无瑕 are associated with purity and no stain. 坦白从宽 means the police order the suspects to tell the truth to receive a lighter sentence, 白衣天使 indicates the nurses who wear white uniform, looking like angels and bringing life and hope to the patients in the hospital. (2)White and 白 symbolizes kindness, inefficacy, in vain. "A white lie" means compiling a piece of excuse because of courtesy instead of cheating others, "a white witch" refers to the witches who do good deeds, "a white sheep" suggests good persons in the bad persons, "a white night" means sleepless night, "a white elephant" indicates something useless, seldom used, or too costly to be worth maintaining, 白卷 means blank examination paper, 白开水 is boiled water, 白费力气, 白费功夫, 白忙 mean in vain. (3)White and 白 also represents failure, paleness and white. In the war, the yielding party will hang "a white flag" or 白旗 as a sign of accepting its failure. White and 白 can be used to describe snow. "A white Christmas” refers to snow at Christmas time as we talk about 白雪皑白岂, “(as) white as a sheet” 
means pale faces because of being frightened or shocked. "A white-faced man" suggests an unhealthy person because of his pale face as in Chinese we have 脸色苍白.

Black and 黑 (1)Black and 黑 are associated with darkness. In English, such expressions as “blackout" and "black fortune" are also connected with "darkness", in Chinese we have 黑暗,黑灯 瞎火,乌黑. “Black tea" refers to a king of tea whose color is dark, "black coffee" is coffee without milk or sugar. (2)Black and 黑 are the symbol of disaster, death and depression. There was a deadly plague in Europe in the $14^{\text {th }}$ century and people named it "the Black Death". In both languages, people have the custom of wearing black for the dead, "to wear black for her father" refers to a person who wears a sackcloth gown as a sign of mourning his father, " a black mood" refers to a fit of depression, bad temper, and usually temporary, though perhaps recurring, "a black dog" means a depressed person. (3)Black means being serious, bad, dirty, unpopular, unlucky, sad, evil, illegal, secret, cruel, annoyed and so on. In both Chinese and English, "black"means, on some occasions, solemnity and dignity, like "a black tie dinner". Black suits and dresses are the favorite raiment of westerners. On the formal occasions, high officials and famous social celebrity all like to be in black; members of symphony orchestra almost wear black suits to indicate dignity and solemnity; in hospitality service, higher managers all are in black. "A black sweat" is similar to 身黑汗 and "black water" is 黑水 in Chinese. "A black day" is a day,or some less specific point of time when something sad or disastrous happens. "A black spot" is a place or area where unpleasant and unwanted things occur regularly and without much change of improvement. "A black sheep" refers to a person regarded as a disgrace or a failure by other members of his family or group. "Black Friday" refers to an unlucky day in honor of Jesus. "A black comedy" or "black humor" refers to a play in which comic elements are combined with more tragic or absurdly evil ones, with the latter on the whole predominating. "A black look" is a look of strong dislike or disapproval. “Black in the face" means anger, which responds to 黑着脸 or 脸色铁青 in Chinese, “to look black at someone" means glaring at somebody. "Black words" means ominous words. Black refers to evil, for example, Satan, the devil is called the prince of blackness. In western culture, people regard "a black cat" as a bad omen: if a person in the morning sees a black cat, then he suddenly senses"today is a black day", which is similar to that Chinese people see a black crow - it is also a bad omen. With the development of computer technology, "hacker" appears who secretly uses or changes the information in other people's computer systems, which means 黑客 in Chinese. In Chinese, there are many Chinese phrases containing 黑 which are in response to the same word "black" in English. 黑心肠 in Chinese describes sinister and ruthless people while there is "black-hearted" in English. The members in reactionary group are called 黑手 in Chinese, which is similar to "black hand"in English. The name list written by dominator to carry out persecution is stated 黑名单 in Chinese or "blacklist" in English. The places which are used to transect illegal goods are called 黑店.黑市(经 营), 走黑道,黑幕,黑夫妻, 黑后台 are all related to illegal deeds, which correspond with "black market" or "black economy" in English. 背黑锅 means be treated unjustly. "Blackmail" means racketeering or extorting, "black sheep" means a prodigal son squandering the family fortune, which responds to 败家子, “a black eye” means disgrace or disrepute.

Differences of Associative Meanings of Basic Color Terms in English and Chinese. Red and 红 In English (1)"Red" means deficit and debt. Such as: "get into the red", "in the red", "red balance".(2)"Red" refers to bureaucracy contempt. "Red-tape" means rather complicated process when dealing with government. Originally the phrase referred to red-colored band to bind government documents in U.K in the early $17^{\text {th }}$ century and came to popularity in the U.S.. In the $19^{\text {th }}$ century, officials in the government departments used to bind documents in red-colored band and dragged to long period of time in the complicated process of handing with people. "Red-neck" is used to describe the Yankees in the south of the U.S., who are despised as Red-Indian or red-skin by the local Indians. In Chinese(1)红 means jealousy, such as:眼红.(2) 红 is associated with revolution, progress and loyalty. In Chinese 红色政权,红军,红色根据地,红旗,红星,赤卫队,红色 
娘子军 are related to revolution.根红苗正 and 红卫兵 imply that someone was born in a poor and progressive family without any counterrevolutionary influence. 一颗红心永向党 implies that someone is steadfast to the communist beliefs and principles.

(3)红 is linked to anti-corruption. Nowadays,红通嫌犯 and(百名)红通人员 refers to those wanted by the Chinese government who fled abroad to escape corruption.

Yellow and 黄 In English (1)Yellow is often associated with abjectness, shyness, suspect and timidity, etc. In "Bible", Judas betrayed Jesus for 30 coins. Always, Judas were in yellow. That is why yellow is associated with betray and wickedness in English. More examples are as follows: "yellow dog" and "have a yellow streak" means a mean person, "yellow belly" refers to a coward, "yellow looks" means looking at someone with frightening eyes. (2)Yellow represents lofty, immortality and belief. In the Christianism, the "golden cross" hung in the priest's colpus and the "grail", which was used by Jesus Christ in the last supper, symbolizes immortality and belief. In Chinese (1)黄 symbolizes sovereignty and nobleness. 黄色 has also been regarded as the royal color of the Chinese emperors for thousands of years, which used to be fearfully worshiped by the common Chinese people in the feudal society because 黄 stood for the emperor's dignity and power. Here are some phrases:黄袍加身, 黄铖, 黄榜, 黄历, 黄屋, 黄马夹. Besides, the palace where the emperors used to live is made up of red walls and a sloping top covered with a layer of yellow earthen tablets.(2)黄 represents loyalty and justice. 黄花囯女 suggests that a maid sticks to sex morals before getting married. 黄花 refer to the chrysanthemum, one of the four favorite flowers cherished by the traditional Chinese intellectuals. 黄花晚节 and 寒花晚节 refers to those saintly scholars with loyal beliefs and admirable qualities. 黄天不负有心人 means God never disappoints the studious. (3)黄 can symbolize youth and ignorance. In Chinese, 黄 are the initial color of the new sprouts of the plants in spring. Yang Wanli of the Southern Song Dynasty describes spring in the poem A Sketch of the Early Spring(<新春即景〉): 诗家清景在新春, 绿柳才黄半未匀。若待 上林花似锦,出门俱是看花人. People like to describe young inexperienced or physically immature maid with 黄毛Y头, 黄口小儿. 回黄转绿 and 青黄不接 are used to describe the scenic change with the seasonal transition. 黄发垂髺 refers to the old people and children. (4)黄 means out of date, failure and harvest.陈年黄历 and 黄粱美梦 are used figuratively to mean things in the past. 黄 also can be used to indicate failure, like 我和她黄了, 买卖黄了. People often associate 黄 色 with ripe corn because the color of ripe corn is yellow.

Blue and 蓝 In English (1)Blue symbolizes sovereignty, nobleness and sternness. Different from Han nationality, the English-speaking countries prefer blue to yellow. "Blue" is associated with high social status or being aristocratic, so it is regarded as the token of nobleness and sternness. For example: "He is a real blue blood" and "A blue-blooded family". And the "boys in blue" refers to the royal mariners and policemen because they are dressed in blue uniform. In addition, in U.S., a book with the names of famous figures, especially top government official is called "blue book". "Blue ribbon" is regarded as the symbol of the highest honor because the British king used to give an accomplished citizen a badge decorated with it. "Blue-brick university" refers to a famous university. "Blue nose" means a defender who obey the religious rules, "blue laws" is a law to control sexual morals and the drinking of alcohol. (2)Blue symbolizes gloom, depression, illness and pornography. In English culture, "blue" has the meaning of depression and melancholy. Below are the examples: "blue about the gills", "blue devils/blue Monday" and "sing the blues/in a blue mood/ having the blues". "Be blue about future" is pessimistic about future, "the blues music" refers to sad music. Blue also suggests illness. For example, "Beat somebody black and blue" means injuring somebody seriously, " blue baby" is a vivid description of a sick child who has caught up with congenital heart attack. Furthermore, "blue" has a close tie with obscenity, such as "blue film/video/joke/book/talk/gag" and "blue balls" refer to the male venereal disease, "blue revolution" is an euphemism for the sex liberation movement popular in western countries around the 1950's, and a "blue gown" is an euphemistic substitute for a hustler. (3Blue means annoyance, 
surprise, without expectation and fast. "A blue fit" means extreme annoyance or alarm. "Out of blue" and "have the blue" means out of a sudden, without any expectation. "Blue streak" means swiftness. (4)Blue symbolizes justice, fairness and loyalty. "A true blue" is a reliable and loyal man, who never makes a change in his political belief and friendship. "True blue will never stain" means gold remains golden even if it is heated, so we often associate this sentence with a loyal person. And a "blue-eyed" boy refers to a trustable person. (5)Blue is also used in some other senses. For example, "the blue-collar jobs" are manual work, or skilled, semiskilled or unskilled labor. "A blue-chip company" is profitable and safe. "Blue button" refers to the broker, who are permitted to do stocking transaction. "In a blue moon" means a chance occurring rarely. In Chinese (1)蓝 in the phrase 蓝图 means a plan. (2)蓝 means someone is better than his teachers or parents, such as 青出 于蓝而胜于蓝.

Green and 绿 In English (1)Green indicates lacking in experience, freshness, innocence and love. "A green hand" suggests someone who is inexperienced and immature. "As green as grass" refers to someone who is innocent. "A green horn" means a person who is easily fooled. "Remain green forever" means keeping fresh. "Keep a memory green" means still remembering something that occurred a long time ago. "A green wound" means the latest wound and "green meat" means that meat is fresh.In the English version of The Story of the Stone translated by David Hawkes, "green boy" refers to Jia Baoyu while "green delights" is the place where he lives. (2)Green is a symbol of envy. "Green eye", "green with jealous" and "green-eyed" means jealousy. (3)Green represents money. "Green pound" means pound, "green back" indicates dollar, "green power" refers to consortium, "green sheet" means a sheet of government's budget, "green stamp" refers to relief fund. In Chinese (1)Green has the association with females and pornography. 绿 is often mentioned with females, such as:红男绿女,绿男红女依红偎翠, a house a lady lives in is called 翠楼 or 红楼, the window of a girl's room is called 绿窗 or 红窗. The hair of a female is called 绿云 or 绿䰅. The expression in Chinese 戴绿帽子 means to be a cuckold. 青楼 is another Chinese euphemistic expression of brothels[8]. (2)In Chinese culture, 绿 also endowed with bad meaning. In the feudal society, the dress of the government official in a lower position was regularized to be in green, so it also symbolizes humbleness, such as 青衫绿袍. (3)绿 denotes bravery as well as rudeness. In the traditional Chinese culture, 绿林好汉 refers to those who lived in the forests helped the poor by robbing the rich in the ancient time.

White and 白 In English (1)White symbolizes happiness, luck, fortune and legislation. "One of the white days of one's life" and "days marked with a white stone" refer to one's lucky or happy days in his life. "White magic" means the magic helped by God, "white-haired boy" means a favorite loved by many people, "white hope" refers to those who can bring success, "white knight" is associated with those who are successful in the career. "A white spirit" means lofty spirit, "white men" indicates well-educated persons, "white list" refers to the list approved by the government, and "white markets" legal market. (2) White is a symbol of fear, cowardice and large-sized goods and profession. "White goods" means the appliances which are large in size and expensive, "white-livered" is fear or cowardice. A "white-collar" job is a professional, business or clerical employment. (3)White is related with politics, government and economy. "The White House" is the symbol of the power of the U.S. "The White Hall" is a street full of government organizations and "white paper" refers to the formal paper issued by western governments. "White war" means economic war. In Chinese (1) 白 is the symbol of death, ill omen, humble social status, fool and no experience. 白 is a basic taboo color in Chinese traditional culture. For example, when one died, his family members must dress in white, use white to decorate mourning hall, relatives and friends in funeral usually wear a white flower to express their respect and mourn, the family will put up a white couple of couplet on the door, his is called 白事. In the traditional ideas, people regard the white tigers as demons. In Chinese feudal society, the common people were forbidden to dress in any other colors except white, so they were called 白衣 or 布衣, the persons with no position are 白 
丁 or 白身, and their houses are 白屋. White represents foolishness when it's used in the term 白痴, 白面书生 refers to the bookman who is lack of experience. (2)白 contains despise and betray. 白眼 means looking down upon somebody. In traditional Beijing opera, 白脸 stands for betrayer and crafty people. (3)白 means the reactionary and counter-revolutionary. In the Second Civil War, 白 军 refers to the army who fought against the Soviet Union and the army of the communists, “白区” indicates Kuomintang-controlled areas, “白色恐怖” means reactionary rulers caused the terrific social atmosphere by massacre and arrest. (4)白 has other meanings. 真相大白 means the fact made clear,白吃 means eating something without pay,表白 means explaining something for oneself, 白 给 means giving somebody something for nothing, 不分青红皇白 means not telling right or wrong, 白金 is platinum.白蚁 is termite,白昼 is daytime

Black and 黑 In English (1) In business English, "in the black" and "black figure" mean running the business profitable. "Black figure nation" refers to balance of payments surplus, "interest in the black" is interest receivable. "Our accountant is in the black this month" means "having money in the bank account". (2) "Black" refers to a person of a dark-skinned race. Such as a black American, whose language is called "black English", and "black power" is associated with a political movement in favor of the belief that in any country black people should have a share of political and economic power in accordance with the number of black people in that country. However, in the U.S., as a result of African-American Civil War from 1950s to 1970s, it is better to avoid using "black" as a noun because this is often considered offensive. So now people use the polite expression "people of color" to talk about anyone with dark skin. In Chinese (1)黑 means justice, fairness and unselfishness. Yu Chigong in Tang Dynasty is a traditional keeper who stops the evil forces and blesses family peace; Bao Gong in Song Dynasty is an official advocating fairness and unselfishness; Li Kui is a hero in Song Dynasty who robs the rich and assists the poor[9]. (2)黑 stands for reactionary forces. During the Great Cultural Revolution, 黑五类 once referred to five categories of people regarded as public enemies before the late 1970s, namely, landlords, rich peasants, counter-revolutionaries, bad elements(morally degenerate people)and rightists (those condemned for opposing socialism in 1957-1958)[10].

Reasons for Differences of Associative Meaning of Basic Color Terms in Chinese and English. Color is closely related to region. According to the ancient Chinese doctrine, the west represents white tigers and is where God responsible for killing is located. In funeral, all the relatives are in white and decorate a room in white flowers to pay tribute to the death. While in Bible stories, angels always have a pair of white wings with silver white right of rings hovering above their heads. And language develops with the evolution of political and economic system, division and reunion of society and contacts among societies. Such as: during Chinese Cultural Revolution 红宝书, 红卫兵, 红色造反派, 红司令, 红五类, 红旗招展, 全国上下一片红, 中华儿女多 奇志, 不爱红装爱武装. In English, “purple” is associated with dignity, king, royal family for the reason that English royal family members and high-ranking officials used to be dressed in purple. Besides, people in these two cultures have differences in national psychology, which comes from the fact that two peoples have different past experiences and cultural traditions.

\section{Conclusion}

Color words seem to correspond to denotative meaning, but may considerably vary in connotative meaning, emotional meaning and various socio-cultural associations they may arouse in different cultural settings. The studies on connotations of color terms can not only help to learn English, but also enlighten English language learning and teaching. In addition, they also play important roles in the field of translation and cross-cultural communication. 


\section{References}

[1] R.F. Zhan: Modern Chinese Semantics (The Commercial Press, China 1997), p.175.

[2] Z.L.Hu: Linguistics Course (Beijing University Press, China 2011), p.146.

[3] Y.Y. Wang: A Cross-cultural Study on English and Chinese Connotations in Basic Color Terms (MS., Ocean University of China, China 2010), p.15.

[4] J.X. Zhang: A Contrastive Study on Cultural Connotations of English and Chinese Basic Color Words/Characters (MS., Chengdou University of Technology, China 2011), p.20.

[5] K.H.Xu: A Contrastive Study on the Culture Loaded Meaning of Color Words in English and Chinese (MS.,Shandong Normal University, China 2011), p.18.

[6] Y.C.Deng \& R.Q.Liu: Language and Culture [M] (Foreign Language Teaching and Research Press, China 1997), p.208

[7] L.J.Guo: A Contrastive Study on the Connotative Meanings of Basic Color Terms in English and Chinese (MS., Shanxi Normal University, China 2013), P.13.(In Chinese)

[8] Y.G.Yang: A Contrastive Study on Cultural Semantics of English and Chinese Words (Wuhan University Press, China 2008), p.232.

[9] Q.R.Peng: Chinese Science \& Technology Translators Journal, Vol.14 (2001) No.1, p.30. (In Chinese)

[10] H.H.Liu: A Comparative Study on Cultural Association of Basic Color Terms in English and Chinese (MS., Inner Mongolia University, China 2009), p.20. 